\title{
I. Є. Іванов \\ ОСНОВНІ НАПРЯМИ УДОСКОНАЛЕННЯ АДМІНІСТРАТИВНО-ДЕЛІКТНОГО ЗАКОНОДАВСТВА НА СТАДІЇ ПОРУШЕННЯ СПРАВИ ПРО АДМІНІСТРАТИВНИЙ ПРОСТУПОК
}

Постановка проблеми. Права і свободи людини та громадянина забезпечуються спеціальним правоохоронним механізмом, який реалізується, зокрема, через правову регламентацію провадження у справах про адміністративні проступки щодо притягнення винних у вчиненні протиправних дій до відповідальності. Саме гарантування законності процесуальних дій та визначена регламентація діяльності суб'єктів адміністративної юрисдикціï, наділених правами та обов'язками щодо порушення, розгляду справ про адміністративні проступки, є основоположним засобом реалізації прав і свобод особи.

Зважаючи на те, що протокол є важливим процесуальним документом, який офіційно засвідчує факт неправомірних дій, за які передбачена адміністративна відповідальність, то він має бути оформлений належним чином, містити в собі всі дані, необхідні для своєчасного та об'єктивного вирішення питання про наявність у діяннях особи складу адміністративного проступку.

Аналіз останніх досліджень. Проблеми адміністративно-деліктного процесу були предметом досліджень багатьох вчених-адміністративістів: В.Б. Авер'янова, Ю.П. Битяка, Є.В. Додіна, Л.В. Коваля, А.Т. Комзюка, Т.О. Коломоєць, О.В. Кузьменко, Д.М. Лук'янця, М.М. Тищенка, B.K. Шкарупи та інших. Разом із тим, у практичному здійсненні провадження в справах про адміністративні правопорушення й нині допускається багато порушень встановленої процедури, у тому числі і щодо складання процесуальних документів. Одним з таких документів є протокол про адміністративне правопорушення, від правильності складання якого залежить законність усіх інших процесуальних дій.

Метою статті є встановлення проблем у діяльності компетентних органів державної влади щодо складання адміністративних протоколів і формулювання рекомендацій щодо удосконалення норм адміністративно-деліктного законодавства і правозастосовної практики. 
Виклад основного матеріалу. Розгляд справ про адміністративні правопорушення визначає логічну і психологічну основу всього адміністративно-деліктного провадження, чіткість, послідовність, ясність якого сприяє реалізації принципу процесуальної економії. Це зумовлено також і тим, що всі процесуальні дії на цій стадії адміністративно-деліктного провадження носять винятково правовий характер, тобто врегульовані в нормативному порядку або повинні бути врегульовані в такому порядку.

Одним з основних завдань провадження у справах про адміністративні правопорушення є забезпечення правильного застосування норм права, що передбачають адміністративну відповідальність. Вирішення даного завдання здійснюється шляхом встановлення фактичних обставин вчиненого проступку. Під фактичними обставинами розуміються ті дії чи обставини, що відбулися і які необхідно вивчити для того, щоб правильно вирішити справу [1, с. 121]. Від цього етапу першої стадії адміністративно-деліктного провадження здебільшого залежить правильність прийнятого рішення.

Об'єкт пізнання в адміністративному розслідуванні є конкретизованим й визначається законодавцем як фактичні дані, на основі яких встановлюється наявність чи відсутність адміністративного правопорушення, винність даної особи в його вчиненні та інші обставини, що мають значення для правильного вирішення справи.

Під час підготовки до розгляду справи про адміністративне правопорушення, згідно зі ст. 278 Кодексу України про адміністративні правопорушення (КУпАП) [2], посадова особа органу адміністративно-деліктної юрисдикції повинна перевірити, чи правильно складено протокол та інші матеріали справи про адміністративне правопорушення. Під час перевірки протоколів та інших документів суб'єкт адміністративно-деліктної юрисдикції вирішує такі питання: чи складений протокол повноважною посадовою особою; чи дотримані вимоги закону щодо його змісту; чи досить повно викладені всі факти, що мають значення для вирішення справи. Перевіряються відповідність вимогам закону й інші матеріали справи.

Чинне адміністративно-деліктне законодавство не містить вказівок на діiі, які потрібно чинити, якщо протокол та інші матеріали справи про адміністративне правопорушення складені з порушенням встановлених вимог щодо їх оформлення. Дослідження практики діяльності органів адміністративної юрисдикції виявило, що посадові особи, уповноважені розглядати справи, дуже рідко направляють матеріали про адміністративне правопорушення особі, що здійснювала адміністративне розслідування, для усунення недоліків, хоча такі випадки інколи зустрічаються.

Часткове вирішення цієї проблеми вбачається нами в необхідності внесення відповідних змін до КУПАП щодо можливості винесення окремої постанови (ухвали) про направлення неналежно оформлених матеріалів справи про адміністративне правопорушення суб'єкту адміністративного розслідування. У постанові (ухвалі) суб'єкту адміністративної юрисдикції, на нашу думку, має бути зазначено, які порушення були допущені під час складання протоколу про адміністративне правопорушення i iнших 
документів, які необхідно провести додаткові процесуальні дії щодо встановлення доказів (у випадку їх недостатності), які відомості про особу правопорушника повинні бути зазначені в протоколі. Отже для того, щоб протокол виконував свої функції, він повинен відповідати встановленим законодавством вимогам щодо його змісту та форми, дотримання яких $€$ необхідною умовою його законності. Найбільш чітко вимоги, що стосуються змісту протоколу, сформульовані в ст.256 КУПАП.

Відносно форми протоколу про адміністративне правопорушення КУпАП та інші закони України чітких вказівок не містять. Проаналізувавши законодавчі норми щодо протоколу про адміністративне правопорушення, можна зробити висновок, що він має бути складений на паперовому носії інформації. Водночас чітких вказівок, що протокол складається на чистому аркуші паперу або на бланку, не дається.

Більш детально порядок складання протоколу працівниками органів внутрішніх справ наводиться в підзаконних нормативних актах, які регламентують порядок оформлення матеріалів про адміністративні правопорушення в конкретному органі адміністративної юрисдикції, наприклад, в органах поліції - Інструкції з оформлення матеріалів про адміністративні правопорушення в органах поліції [3].

Протокол про адміністративні правопорушення, на нашу думку, повинен складатися на бланках, які $є$ документами суворої звітності і друкуватися із зазначенням серії і номера, хоча закон до цього не зобов'язує. Водночас це не означає, що складений на чистому аркуші паперу, у разі відсутності бланку, протокол буде визнаний недійсним. Навпаки, протокол, складений на чистому аркуші паперу з дотриманням усіх вимог закону, буде мати юридичну силу, а протокол, складений на бланку з порушенням закону, буде вважатися недійсним.

Усі вимоги щодо складання протоколу можна розділити на три основні групи. Перша група вимог стосується встановлення обставин самого факту вчинення адміністративного проступку. У протоколі під час викладення обставин правопорушення вказується число, місяць, рік, час його вчинення, суть правопорушення, які саме протиправні дії вчинила особа, яка притягається до адміністративної відповідальності. Усі ці дані мають важливе значення, їх не можна вважати лише формальністю. Уповноважена особа, яка здійснює розслідування, повинна ретельно розібратися в характері правопорушення й правильно кваліфікувати дії винного. У протоколі необхідно об'єктивно зазначити ті обставини, які свідчать про наявність адміністративного проступку та його характер.

Від точного опису в протоколі дій, що здійснила особа, яка притягається до адміністративної відповідальності, залежить і правильність кваліфікації іï проступку. Опис таких дій повинен бути чітким і стислим. Ліричні відступи в описовій частині протоколу не допускаються. Більш детальний опис обставин вчинення правопорушення може бути зроблений у поясненнях особи, яка притягається до адміністративної відповідальності, свідків, потерпілого. Ці пояснення можуть подаватися на окремих аркушах і 
додаються до матеріалів справи. Обов'язково зазначається нормативний акт, який встановлює відповідальність за даний вид правопорушення, й конкретна його стаття.

Окреме питання стосується зазначення в протоколі відомостей про повторне вчинення адміністративного правопорушення, особливо коли це має значення за умови кваліфікації діяння правопорушника, як повторного. Не завжди посадова особа органів внутрішніх справ на момент складання протоколу про адміністративне правопорушення володіє інформацією про повторність вчинення особою правопорушення. У більшості випадків така інформація потребує перевірки (як правило, через технічні засоби інформації - картотеки, бази даних електронних засобів інформаціі), що одразу після виявлення факту правопорушення здійснити на сьогодні неможливо. Тому доволі часто інформація про повторність вчинення особою правопорушення заноситься до протоколу зі свідчень самого правопорушника або інших учасників провадження - свідків, очевидців. Якщо в результаті перевірки така інформація не підтверджується, протокол вважається складеним із порушенням законодавства і не може бути документальним доказом у справі. Тому вважаємо за доцільне відомості про повторність вчинення правопорушення заносити до протоколу лише у випадку їх підтвердження за результатами перевірки. Якщо ж такі відомості підтверджуються після складання протоколу, їх необхідно долучити до матеріалів справи і врахувати в процесі винесення і складення постанови про накладення адміністративного стягнення.

Друга група вимог пов'язана із закріпленням різних обставин, що характеризують особу, яка притягається до адміністративної відповідальності. Стаття 256 КУпАП дуже стисло вказує, що повинно бути зазначено в протоколі про адміністративне правопорушення серед «відомостей про особу порушника» і не дає переліку таких відомостей.

Мінімальною кількістю відомостей про особу, яка притягається до адміністративної відповідальності (з метою іï ідентифікаціі), можна вважати: повне прізвище, ім'я та по батькові; число, місяць і рік народження; повна адреса місця народження особи; фактичне місце проживання особи на час вчинення правопорушення. Такий перелік відомостей про особу дає з доволі високою вірогідністю сказати, що саме ця особа вчинила правопорушення.

Згадана Інструкція з оформлення матеріалів про адміністративне правопорушення, окрім зазначених відомостей про особу, вимагає включати до протоколу й інші відомості, які безпосередньо не дають ознак для ідентифікаціі особи, але дозволяють більш точно індивідуалізувати накладення адміністративного стягнення. Так, відомості про громадянство особи дають можливість до іноземців та осіб без громадянства за вчинення грубих адміністративних правопорушень застосовувати адміністративне видворення цих осіб за межі України.

Інструкція вимагає внесення до протоколу про адміністративні правопорушення також наступних даних: про найменування підприємства, уста- 
нови, організації, де працює або навчається особа, та іï посаду; середньомісячний заробіток або інші доходи особи, яка вчинила правопорушення; кількість осіб, які знаходяться на ії утриманні. Ці дані дають можливість більш диференційовано підходити до виду та розміру адміністративного стягнення або передати матеріали про адміністративне правопорушення на розгляд громадської організації чи трудового колективу.

Протокол може бути складений лише відносно громадянина, особу якого підтверджено документами чи свідками. Основними документами, які підтверджують особу, є паспорт громадянина України, паспорт громадянина України для виїзду за кордон, паспорт, який підтверджує громадянство іншої країни. На практиці для встановлення особи доводиться використовувати й інші документи: військовий або студентський квиток, пенсійне посвідчення, перепустку тощо. Можливо також використовувати картотеку адресного бюро. Безумовно, такі заходи значно підвищують ризик помилки під час ідентифікації особи. Керуватися під час складення протоколу лише даними, отриманими від самого правопорушника, не можна. Непоодинокі випадки, коли правопорушники, аби уникнути відповідальності, називали не свої прізвища та імена. Це ж, але рідко, трапляється, коли особа правопорушника встановлюється за показаннями свідків. У практичні діяльності органів внутрішніх справ були випадки, коли через невірне встановлення особи навіть до кримінальної відповідальності притягалися інші особи.

Третя група вимог стосується форми протоколу. Форма правового акта не означає непотрібної формальності. Форма відбиває конкретний зміст й має певну цінність. В інтересах дотримання принципу законності в Кодексі України про адміністративні правопорушення та нормативних актах відповідних органів, що регламентують документальну форму протоколу, закріплено конкретні вимоги щодо форми протоколу про адміністративне правопорушення [4; 5]. Недотримання цих вимог може призвести до визнання протоколу недійсним чи його зміни. Тому не можна допускати нівелювання значення форми протоколу про адміністративне правопорушення [6, с. 32].

У протоколі зазначається дата й місце його складення, посада, прізвище ім'я та по батькові особи, яка склала протокол, прізвища й адреси свідків, якщо вони були. Відсутність відомостей про особу, яка склала протокол, означає те, що протокол визнається недійсним, адже невідомо, чи складений він уповноваженою на це особою чи ні.

Обов'язковим реквізитом протоколу $є$ дані про роз'яснення особі, яка притягується до відповідальності, іiі прав та обов'язків, передбачених ст. 268 КпАП, про що свідчить підпис цієї особи. На необхідність їх обов'язкового і повного доведення особі, відносно якої складається протокол, наголошувалось вище. Протокол підписується кількома особами, насамперед особою, яка склала протокол, та правопорушником. Останній повинен бути ознайомлений зі змістом протоколу й може внести до нього свої пояснення чи викласти своє мотивування щодо відмови від його під- 
писання. Така відмова не $є$ перепоною для подальшого розвитку справи. Але вона обов'язково має бути зафіксована в протоколі. Ми вважаємо за доцільне підтверджувати цю відмову підписами понятих. За наявності свідків й потерпілих, протокол може бути підписаний й цими особами.

Висновки. Проведене дослідження результатів практики застосування норм адміністративно-деліктного законодавства на стадії порушення справи про адміністративний проступок свідчить про необхідність впровадження низки положень, а саме:

1) розширення обов'язкових обставин та відомостей (реквізитів), які повинні зазначатись у протоколі про адміністративне правопорушення;

2) обов'язкової реєстрації протоколу в органі адміністративної юрисдикції, що здійснює попереднє розслідування справи, та вручення його копії особі, яка притягається до відповідальності, та потерпілому;

3) виключення можливості оформлення матеріалів справи без складення протоколу про адміністративне правопорушення;

4) визначення моменту та процесуального порядку порушення справи про адміністративний проступок та завершення ії адміністративного розслідування.

\section{Література}

1. Колпаков В.К. Адміністративна відповідальність: навч. посіб. К.: Юрінком Інтер, 2008. 256 c

2. Кодекс України про адміністративні правопорушення. Відомості Верховної Ради УРСР. 1984. Дод. до № 51. Ст. 1122.

3. Про затвердження Інструкції з оформлення матеріалів про адміністративні правопорушення в органах поліції: наказ МВС України від 06.11.2015 № 1376. Офіційний вісник України. 2015. № 99. Ст. 3405.

4. Про затвердження Інструкції з оформлення матеріалів про адміністративні правопорушення та визнання такими, що втратили чинність, деяких наказів МНС України: наказ МНС України від 27.07.2016 № 725. URL: http:/ / zakon5.rada.gov.ua/laws/show/z1162-16.

5. Про затвердження Інструкції з оформлення матеріалів про адміністративні правопорушення: наказ Міністерства юстиції України від 19.12.2011 № 3539/5. Офіційний вісник України. 2011. Ст. 3592.

6. Процесуальний примус в адміністративній відповідальності: монографія / В.К. Колпаков, В.В. Гордєєв, І.М. Сопілко та ін. Х.: Харків юридич., 2011. 416 с.

\section{Анот а ц і я}

Іванов I. Є. Основні напрями удосконалення адміністративно-деліктного законодавства на стадії порушення справи про адміністративний проступок. - Стаття.

Стаття присвячена теоретико-правовій характеристиці змісту і форми протоколу про адміністративне правопорушення, окреслено проблеми його складання. Здійснено аналіз практики адміністративно-юрисдикційної діяльності компетентних органів державної влади на стадії порушення справи про адміністративний проступок. За результатами дослідження сформулювало конкретні пропозиції щодо удосконалення вітчизняного адміністративно-деліктного законодавства.

Ключові слова: адміністративне провадження, адміністративний проступок, адміністративна відповідальність, адміністративний протокол. 


\section{Ан нот а ци я}

Иванов И. Е. Основные направления совершенствования административно-деликтного законодательства на стадии возбуждения дела об административном проступке. - Статья.

Статья посвящена теоретико-правовой характеристике содержания и формы протокола об административном правонарушении, очерчены проблемы его оформления. Осуществлен анализ практики административно-юрисдикционной деятельности компетентных органов государственной власти на стадии возбуждения дела об административном проступке. По результатам исследования сформулированы конкретные предложения относительно усовершенствования отечественного административно-деликтного законодательства.

Ключевые слова: административное производство, административный проступок, административная ответственность, административный протокол.

\section{S u m m a r y}

Ivanov $I$. Ye. The main directions of perfection of administrative and delinquent legislation at the stage of initiating an administrative offense case. - Article.

The article is sanctified to legal description of maintenance and form of protocol about an administrative crime, the problems of his stowage are outlined. The analysis of practice of jurisdiction activity of competent public authorities is carried out on the stage of raising action about administrative misconduct. On results research set forth concrete suggestions in relation to the improvement of home tort legislation.

Key words: administrative realization, administrative misconduct, administrative responsibility, administrative protocol. 